\title{
Classification and characteristics of tight oil plays
}

\author{
Xin-Shun Zhang ${ }^{1} \cdot$ Hong-Jun Wang ${ }^{1} \cdot$ Feng Ma $^{1} \cdot$ Xiang-Can Sun ${ }^{2} \cdot$ \\ Yan Zhang ${ }^{1} \cdot$ Zhi-Hui Song $^{1}$
}

Received: 6 February 2015/Published online: 21 January 2016

(c) The Author(s) 2016. This article is published with open access at Springerlink.com

\begin{abstract}
Based on the latest conventional-unconventional oil and gas databases and relevant reports, the distribution features of global tight oil were analyzed. A classification scheme of tight oil plays is proposed based on developed tight oil fields. Effective tight oil plays are defined by considering the exploiting practices of the past few years. Currently, potential tight oil areas are mainly distributed in 137 sets of shale strata in 84 basins, especially South America, North America, Russia, and North Africa. Foreland, craton, and continental rift basins dominate. In craton basins, tight oil mainly occurs in Paleozoic strata, while in continental rift basins, tight oil occurs in Paleozoic-Cenozoic strata. Tight oil mainly accumulates in the Cretaceous, Early Jurassic, Late Devonian, and Miocene, which correspond very well to six sets of globaldeveloped source rocks. Based on source-reservoir relationship, core data, and well-logging data, tight oil plays can be classified into eight types, above-source play, below-source play, beside-source play, in-source play, between-source play, in-source mud-dominated play, insource mud-subordinated play, and interbedded-source play. Specifically, between-source, interbedded-source, and in-source mud-subordinated plays are major targets for global tight oil development with high production. In
\end{abstract}

Xin-Shun Zhang

vvvzxs@126.com

1 Research Institute of Petroleum Exploration \& Development, PetroChina, Beijing 100083, China

2 Oil \& Gas Survey, China Geological Survey, Beijing 100029, China

Edited by Jie Hao contrast, in-source mud-dominated and in-source plays are less satisfactory.

Keywords Tight oil - Distribution characteristics · Play · Source-reservoir relationship · Classification · Estimated ultimate recovery (EUR) · Efficiency evaluation

\section{Introduction}

With the rapid advances in exploration theory and technology, a majority of conventional oil resources have been discovered, leaving less and less potential oil resources in place. The great potential of unconventional oil resources has been confirmed by successive breakthroughs in exploration and development (Jarvie 2012; Jia et al. 2012; Zhao et al. 2013; Zou et al. 2014; Pang et al. 2015). As an unconventional resource that is most similar to conventional oil resources, tight oil has become a focus for global exploration and development, and a historic breakthrough has been achieved in North America (EIA 2013; BP 2015; IHS 2014a, b). In 2014, the US' tight oil production reached 3.2 MMbbl/d (165 million tons/year), which accounted for $40 \%$ of total oil production in the country. That figure is still increasing. In the third quarter of 2014, the tight oil production in the Bakken Formation (Williston Basin) and Eagle Ford Formation (Gulf Basin) exceeded 1 $\mathrm{MMbbl} / \mathrm{d}$ (50 million tons/year), respectively (Hart Energy 2014). In China, although the resources are great (Wang et al. 2015), the annual tight oil production was less than 10 million tons in 2013 and the Chang- 6 and Chang-7 formations in the Ordos Basin were the main producing areas, with annual production up to 800 million tons. Breakthroughs have been made in tight oil exploration in the Qingshankou Formation of the Songliao Basin, the 
Permian Formation of the Junggar Basin, and the Jurassic Formation of the Sichuan Basin, but these formations are not ready for commercial development (Zou et al. 2014; Jia et al. 2014).

A lot of research has focused on pore-throat structures, development environments, and distributions of tight oil reservoirs in multiple regions (Liang et al. 2011; Kuang et al. 2012; Zhou and Yang 2012; Yang et al. 2013; Zhang et al. 2013; Pang et al. 2015). However, scholars have showed less concern about tight oil plays, since they believe that tight oil accumulated near or in source formations (Jia et al. 2012; Zou et al. 2014). This paper is a further study of "Unconventional Hydrocarbon Potential Analysis and Future Strategic Zone Selection in Global Main Areas"- - a key subject under the National Oil and Gas program. This program is aimed to appraise the global unconventional resources evaluated by China National Petroleum Company (CNPC). We analyzed 28,992 wells of North American tight oil plays, including 10,653 tight oil production wells and 16,829 wells with logging data (Fig. 1). All these well data were purchased from the IHS unconventional oil and gas database, which was updated to 2014. To make the result integral and reliable, we also reviewed many other reports (C \& C Reservoirs 2014), which focus on global tight oil exploration and development situations and characteristics of mature tight oil areas. Tight oil reservoirs are classified by the types of sourcereservoir relationship, and the efficiencies of different tight oil reservoirs are analyzed according to the development features in North America. In this way, favorable plays are defined to provide reference for tight oil exploration.

\section{Definition of tight oil}

Tight oil is variously defined but mainly as follows: (1) Tight oil is one of the oil resources where the shale is the source rock and the oil also accumulates in shale or nearby. It generally refers to shale oil, similar to shale gas. Shale oil reservoirs have poor properties due to low connectivity of micro-pores in the shale. Oil in such tight shale reservoirs is explicitly defined as shale oil by IEA and some Chinese organizations. (2) Tight oil, similar to tight gas, is a petroleum resource produced from ultra-low permeability shale, siltstone, sandstone, and carbonate, which are closely related to oil-source shales. This resource is defined as "light tight oil" by IEA and "tight oil" by Statoil, EIA, and some Chinese scholars (EIA 2011; Zou et al. 2012). (3) All petroleum resources that must be produced economically from low-permeability and low-porosity reservoirs by stimulation treatments (e.g., hydraulic fracturing) are referred to as tight oil, without limitations of lithology and oil quality. This definition is similar to that of IHS and National Resources Canada (NRC 2012; IHS 2014a, b).

Although the definition of tight oil is distinct, a common understanding is that tight oil accumulates in low-porosity and low-permeability reservoirs and it can be recovered economically only by artificial stimulation

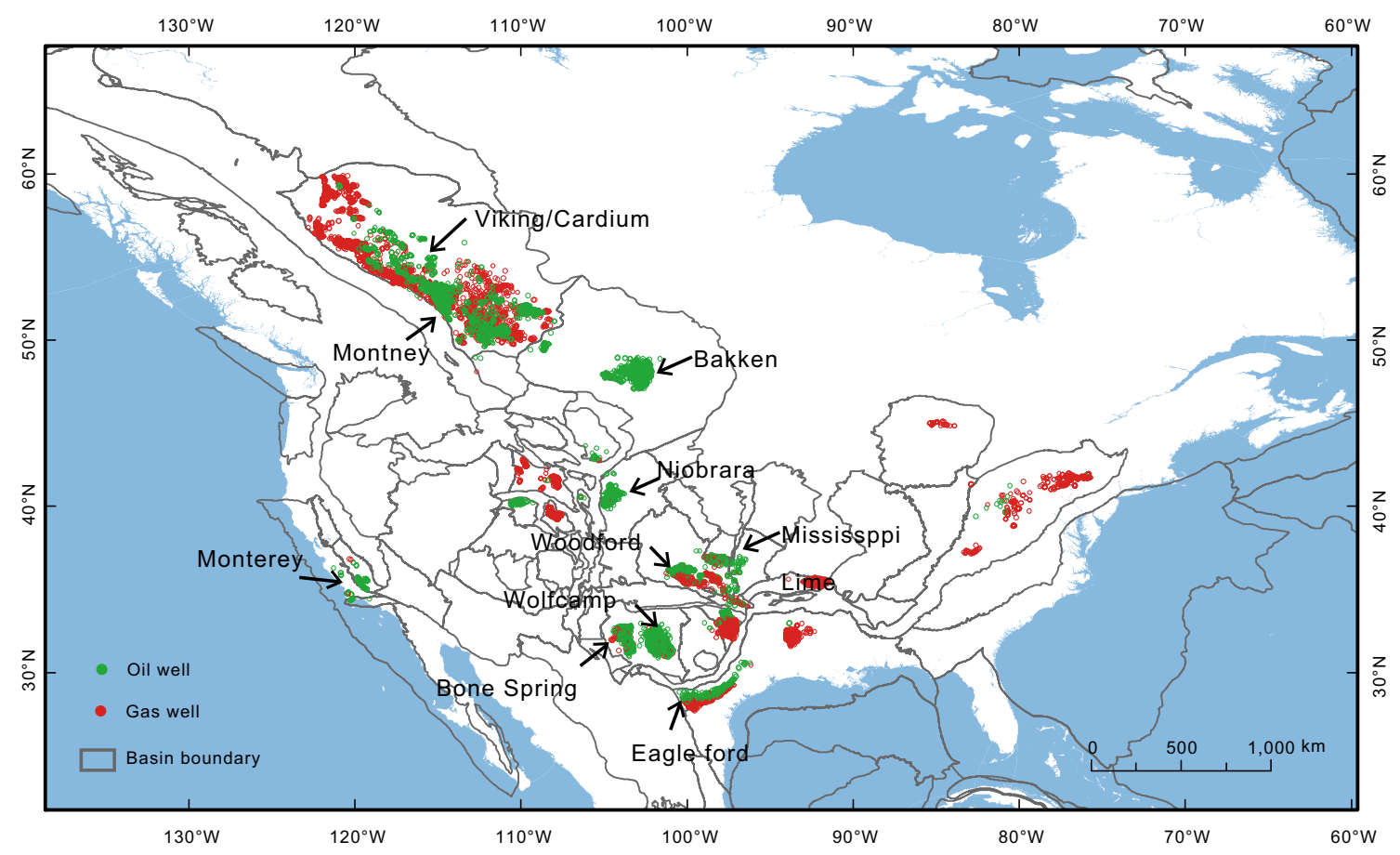

Fig. 1 Distribution map of unconventional drilling well data, North America. Notes data from IHS unconventional database, 2014 
(Pang et al. 2014). Based on international research in recent years, tight oil is defined in this paper as the oil resource that is preserved and accumulated in lowporosity $(<12 \%)$ and low-permeability (overburden matrix permeability $<0.1 \mathrm{mD}$ ) shale, siltstone, sandstone, carbonate, or other tight reservoirs, in or near source rocks under the control of one or more sets of highquality source rocks (Table 1). Shale oil often accumulates continuously at large scale without trap boundaries and with almost no natural productivity.

\section{Distribution of tight oil}

The quality of source rocks is the most significant aspect for evaluating the unconventional resource abundance. In this study, the tight oil basins are selected by TOC higher than $1 \%$, vitrinite reflectance $R_{\mathrm{o}}$ of $0.7 \%-1.2 \%$, and crude oil API higher than $38^{\circ}$ (Ma et al. 2014; CNPC 2014). Therefore, 84 basins (137 tight oil strata series totally) are selected from 468 basins globally for evaluation (Fig. 2), and their tight oil potential is more than 240 billion barrels preliminarily estimated by volume method.

Tight oil is most prolific in North America, South America, North Africa, and Russia, but less prolific in Asia and Oceania. The hydrocarbon mainly accumulates in foreland basins, continental rift basins (Mesozoic strata), and craton basins (Paleozoic strata), and less in passive margin basins (Mesozoic strata) and back-arc basins (Cenozoic strata), as shown in Fig. 3.

Tight oil mainly accumulates in Silurian, Late Devonian, Permian, Late Jurassic, Middle Cretaceous, and Oligocene-Miocene (Fig. 4), which are well correlated with the six sets of high-quality source rocks that are globally widespread (Klemme and Ulmishek 1991). Generally, $78 \%$ of tight oil reservoirs are marine sediments; the corresponding organic matter of source rocks are mainly Type II (48 \%), Type II/III (25\%), Type I/II (18\%), Type III (5\%), and Type I (4\%); TOC mainly ranges from $2 \%$ to $5 \%$, and $R_{\mathrm{o}}$ mainly from $0.9 \%$ to $1.1 \%$. In view of organic matter abundance, the average TOC of tight oil reservoirs in Europe-Russia, North America, and Africa exceeds $4 \%$, which is significantly higher than that in South America, Asia, and Oceania. Tight oil resources are more prolific in the former regions due to the higher average TOC. The average porosity of tight oil reservoirs mainly ranges between $5 \%$ and $7 \%$, or even reaches $10 \%$ locally. The tight oil resources in North America and South America are prospective for commercial development due to relatively high average reservoir porosity. Marine sediments dominate global tight oil reservoirs, and continental sediments mainly develop in Asia.

\section{Types of tight oil plays}

\subsection{Classification of tight oil plays}

Tight oil mainly accumulates in or near source rocks under the control of one or more sets of high-quality source rocks without trap boundaries. Therefore, according to the spatial relationships between tight oil reservoirs and high-quality source rocks, tight oil plays can be classified into eight types, above-source play, below-source play, beside-source play, in-source play, between-source play, in-source muddominated play, in-source mud-subordinated play, and interbedded-source play (Table 1). For above-source, below-source, and beside-source plays which generally have conventional hydrocarbon features, high-quality source rocks and reservoirs are completely separated, and hydrocarbons migrate from source rocks to and accumulate in reservoirs; obvious segmentations with low gamma high resistivity of reservoirs and high gamma low resistivity of source rocks are found in well-logging curves. For insource plays, reservoir rocks are not developed but source rocks serve as reservoirs; the reservoir space mainly consists of organic pores with high gamma in the whole section. For between-source play, hydrocarbon can be supplied from both the upper and lower source rocks of reservoirs, and the monolayer of reservoir rocks is generally very thick (usually greater than $2 \mathrm{~m}$ ); in the well logging, reservoir rocks are often characterized by low gamma and high resistivity, which can be easily identified and can be developed as a separate reservoir.

When multiple sets of source rocks and reservoir rocks with a small monolayer thickness (less than $2 \mathrm{~m}$ ) are interbedded vertically, the reservoir cannot be fully distinguished by well logging, and the monolayer cannot be considered separately in practice. Therefore, this reservoir can be sub-classified into in-source mud-subordinated play, in-source mud-dominated play, and interbedded-source play according to the shale-formation thickness ratio. These plays are featured by zigzag pattern in the wholesection well-logging curves with neither low gamma high resistivity of reservoirs nor high gamma low resistivity of source rocks. In-source mud-dominated plays approximate source rocks, and in-source mud-subordinated plays approximate reservoir rocks due to different shale-formation thickness ratios.

\subsection{Typical characteristics of tight oil plays}

Similar to conventional hydrocarbon plays, above-source plays contain major source rocks below the reservoir rocks and the tight oil reservoir closely overlying source rocks. By contrast, the above-source play has a tight reservoir, 


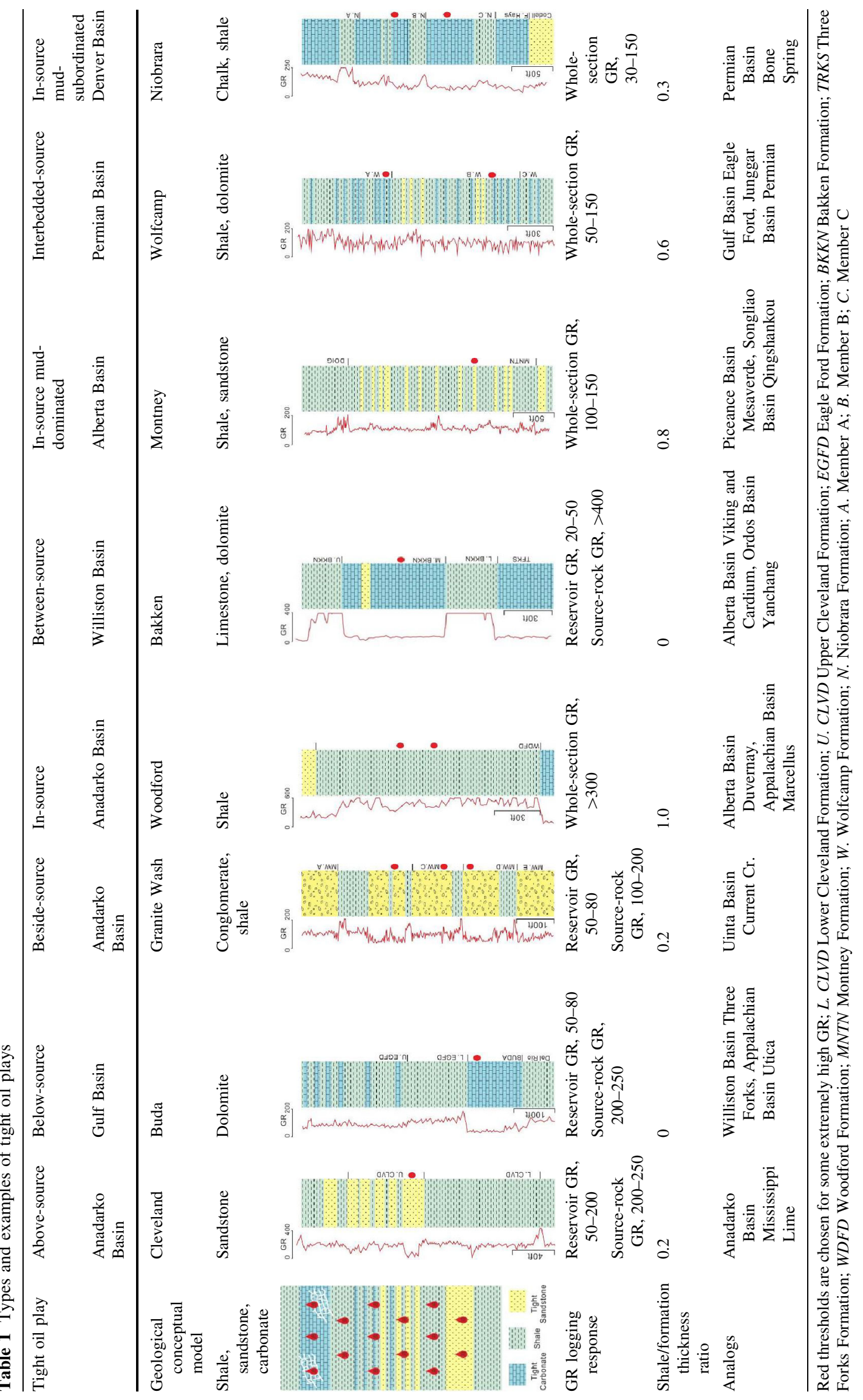




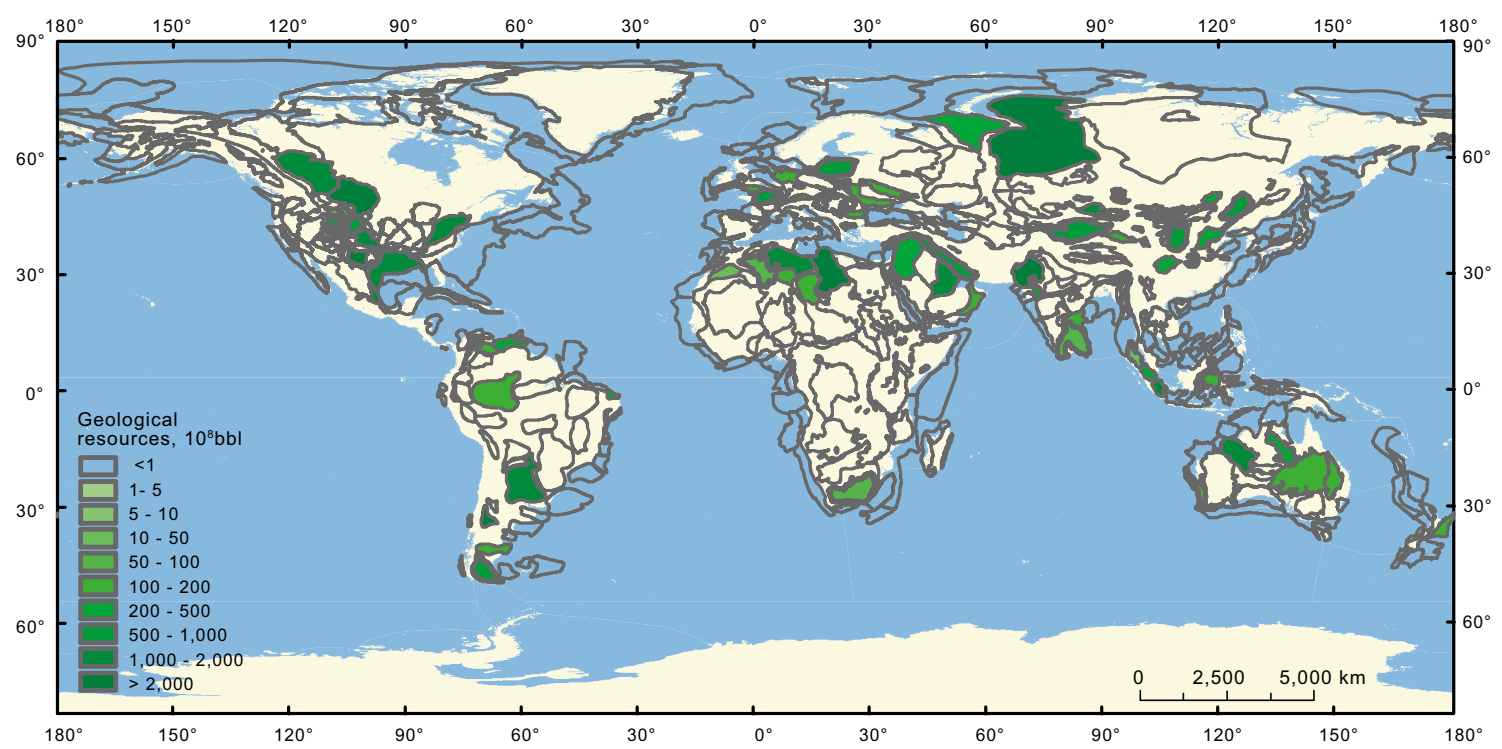

Fig. 2 Distribution of global tight oil resources (Notes sorted as per relevant data of USGS, EIA, and IHS)

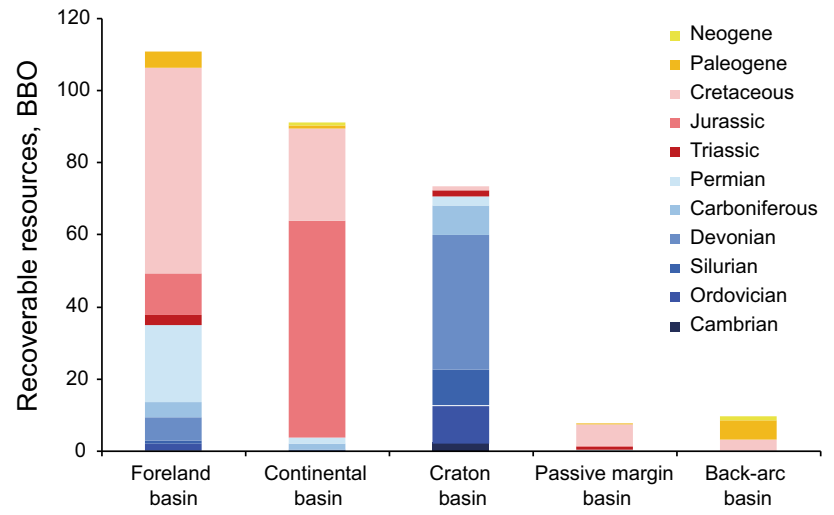

Fig. 3 Types of global basins with tight oil (Notes sorted as per relevant data of USGS, EIA, and IHS)

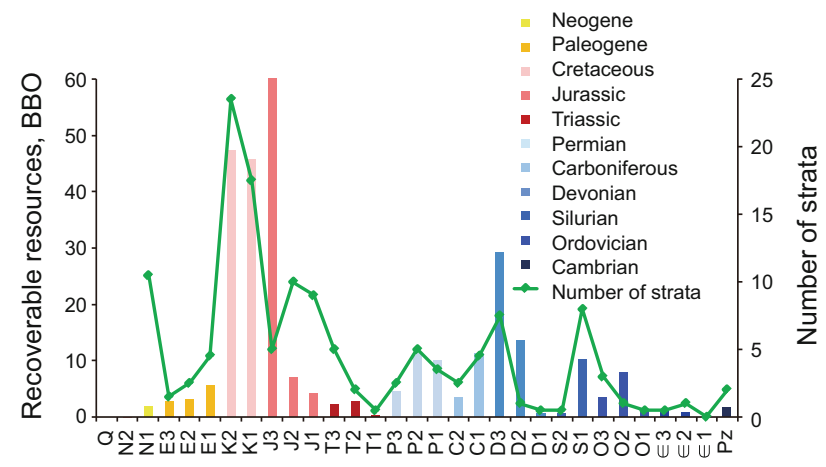

Fig. 4 Stratigraphic ages of global tight oil (Notes sorted as per relevant data of USGS, EIA, and IHS. From left to right, the ages become older, and $J 1$ Lower Jurassic; $J 2$ Middle Jurassic; J3 Upper Jurassic; $P z$ Precambrian) where oil is not controlled by buoyancy and can only migrate for a short distance. If the reservoir is not tight enough, conventional hydrocarbon rather than tight oil accumulates due to lateral hydrocarbon migration. The Cleveland tight oil play in the Anadarko Basin is a typical case, in which the major producing reservoir is a set of 15 m-thick sandstones in the Upper Cleveland Formation, and the source rocks are a set of mudstones in the Lower Cleveland Formation (Table 1) (Ambrose et al. 2011). Similarly, for the Mississippi limestone tight oil play in the Anadarko Basin, hydrocarbon is supplied by lower organic-rich marl and lower Woodford mudstone, and the high-productivity reservoir is mainly the section with relatively well-developed dolomite in the upper Mississippi Formation (Fig. 5a, b).

For below-source play, source rocks overlie tight oil reservoirs, and oil overcomes buoyancy and migrates into lower adjacent reservoirs under the action of the pressure difference between source rocks and reservoirs. In the Three Forks dolomite tight oil play in the Williston Basin (Fig. 5b), oil is mainly generated in high-quality source rocks of the Lower Bakken Formation (Nordeng and Helms 2010). The Buda dolomite tight oil play in the Gulf Basin lies below the high-quality source rocks of the Lower Eagle Ford Formation (Hentz and Ruppel 2010) (Fig. 6b). Similar plays also include the Tuscaloosa sandstone tight oil play in the Gulf Basin (Bebout et al. 1992) and Lower Qingshankou Fuyu tight oil reservoirs in the Songliao Basin.

For beside-source plays, there is obvious lateral distinction between source rocks and tight oil reservoirs, and oil from source rocks migrates laterally into tight 

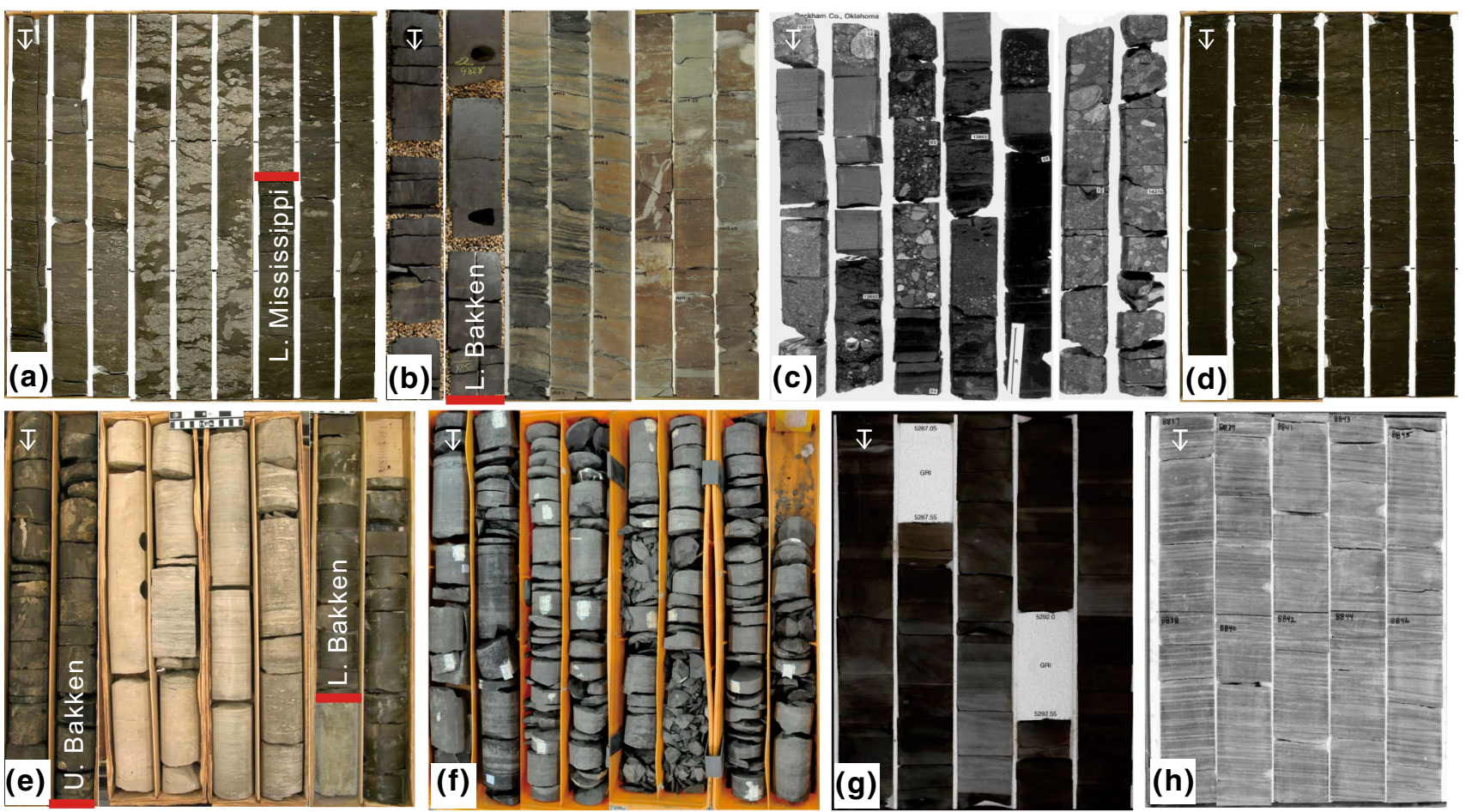

Fig. 5 Core sample photographs of different tight oil plays (Data source C \& C Reservoir). a Above-source play, Mississippi limestone, middle and upper are dolomitic limestone, lower is organic-rich marlstone. b Below-source play, Three Forks Formation, mainly dolomite, upper is Bakken shale. c Beside-source play, mix of granite wash, conglomerate, sandstone, shale. d In-source play, Woodford Formation, mainly shale with occasional thin sandstone. e Between-source play, Bakken Formation, both upper and lower are organic-rich shales, middle is dolomitic siltstone. f In-source mud-dominated play, Qingshankou Formation, middle and upper are dolomitic limestone, lower is mudstone. $\mathbf{g}$ Interbedded-source play, Wolfcamp Formation, upper is mainly interbedded siltstone and shale, lower is interbedded dolomite and shale. $\mathbf{h}$ Insource mud-subordinated play, Bone Spring Formation, mainly sandstone and siltstone with interbedded thin shale

reservoirs. This play type often develops in steep piedmont zones, where alluvial fans exist, a large amount of detritus rapidly accumulates into the lake or sea and laterally interacts with organic-rich shale. For the Granite Wash in the Anadarko Basin, a conglomerate tight oil play, crude oil is supplied laterally by multiple sets of source rocks (Mitchell 2011); the tight oil reservoirs are very thick (usually more than $100 \mathrm{~m}$ ), but they are not well developed and become rapidly thinner towards the basin, which are dominated by low-porosity and low-permeability conglomerate (Figs. 5c, 6c).

For between-source plays, the major reservoirs are tight formations between multiple sets of high-quality source rocks. The Bakken tight oil play in the Williston Basin is a typical case, where the middle section is a set of tight limestone reservoirs with interbedded siltstone (Fig. 5d), and both the upper and lower sections are high-quality source rocks with an average TOC of $11 \%$ (Sonnenberg and Pramudito 2009; Angulo and Buatois 2012), which form a favorable "sandwiched" combination (Fig. 6d). Therefore, tight oil resources in this basin are the most prolific in the world. The Yanchang-6 and Yanchang-7 formations in the Ordos Basin are also attributed to this kind of play, which are major contributors of tight oil in China.

For in-source plays, tight oil generates and accumulates in source rocks, and the corresponding shale-formation thickness ratio is higher than 0.9 . Well logging can hardly recognize sandstone or carbonate layers in these formations, nor reservoir rocks of massive sandstone or carbonate. Typically, in the Woodford tight oil play in the Anadarko Basin, the whole section is shale (Figs. 5e, 6e), and the GR value is $300-700$ API. However, the quartz content in the vertical direction varies inside this shale formation, and the high silica section is the primary

Fig. 6 Types and examples of tight oil plays (Data source IHS unconventional database. Thresholds are chosen for some extremely high GR. Red point represents the main production layers). a Abovesource play, Mississippi Formation, Anadarko Basin. b Below-source play, Buda Formation, Gulf Basin. c Beside-source play, Granite Wash Formation, Anadarko Basin. d Between-source play, Bakken Formation, Williston Basin. e In-source play, Woodford Formation, Anadarko Basin. f In-source mud-dominated play, Montney Formation, Alberta Basin. $\mathbf{g}$ Interbedded-source play, Wolfcamp Formation, Permian Basin. h In-source mud-subordinated play, Niobrara Formation, Denver Basin 
(a)

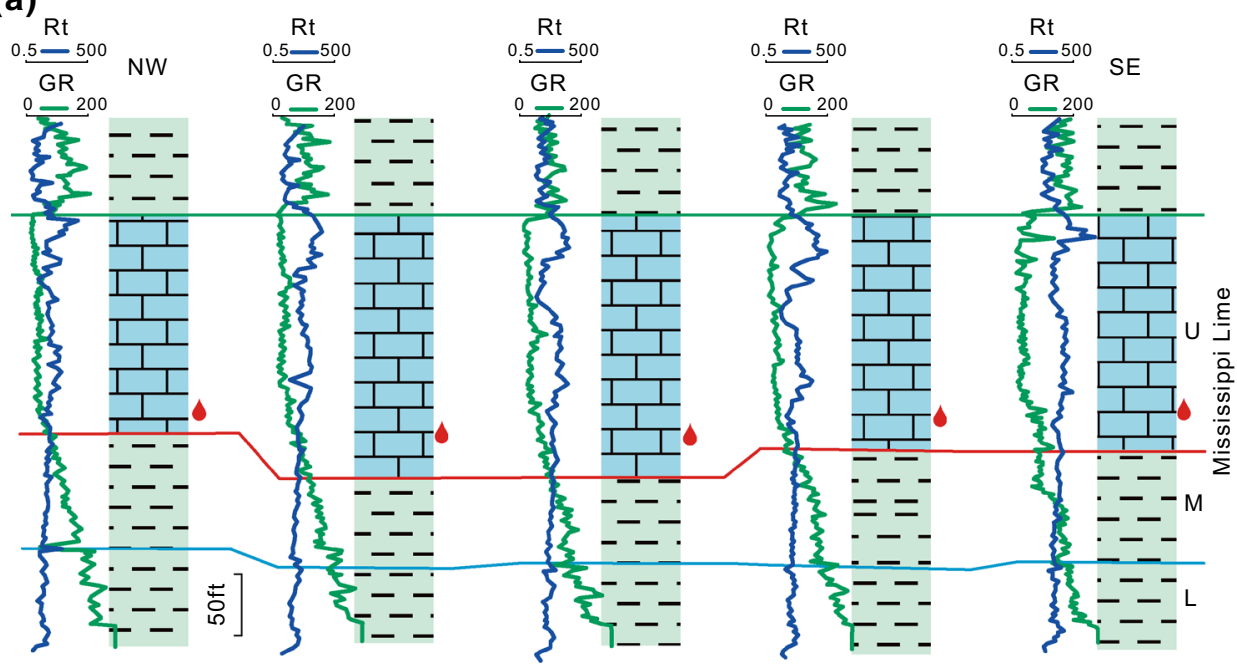

(b)

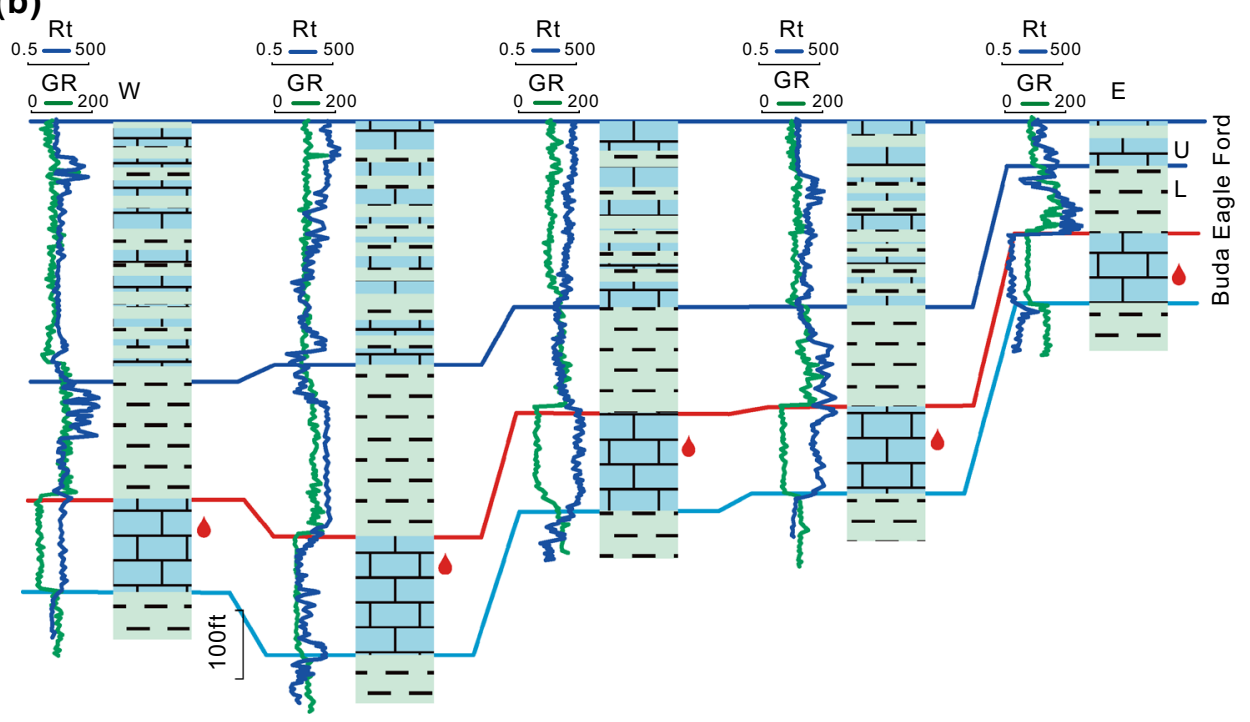

(c)

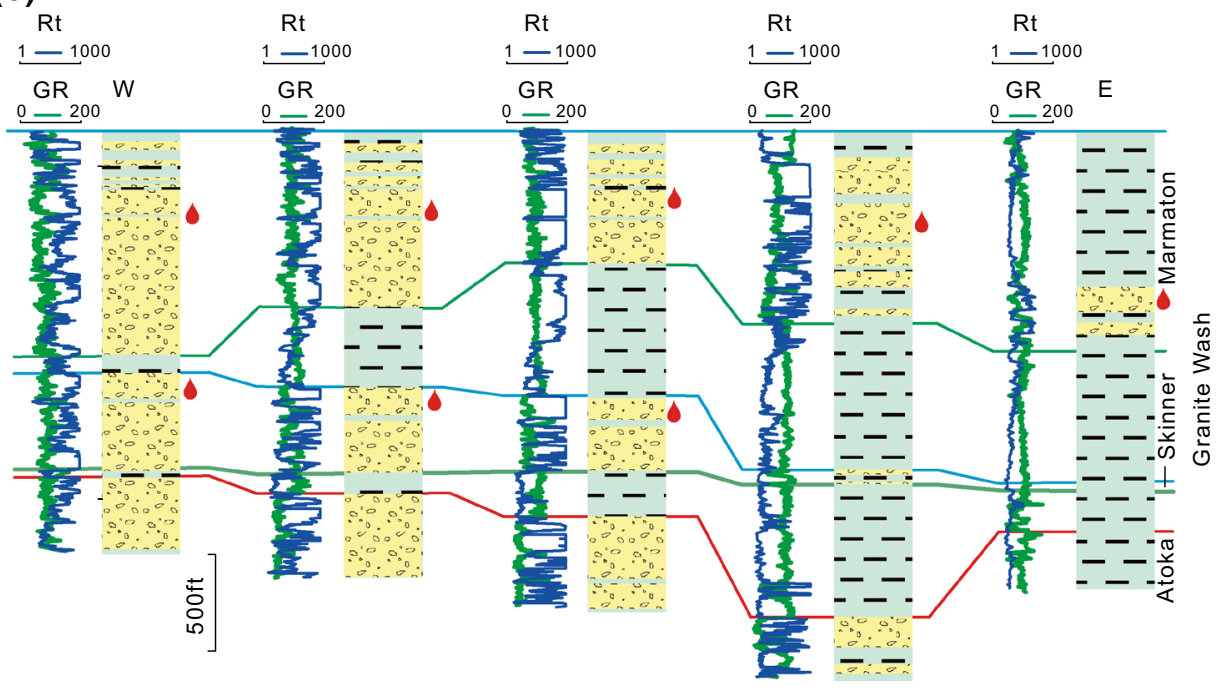


(d)

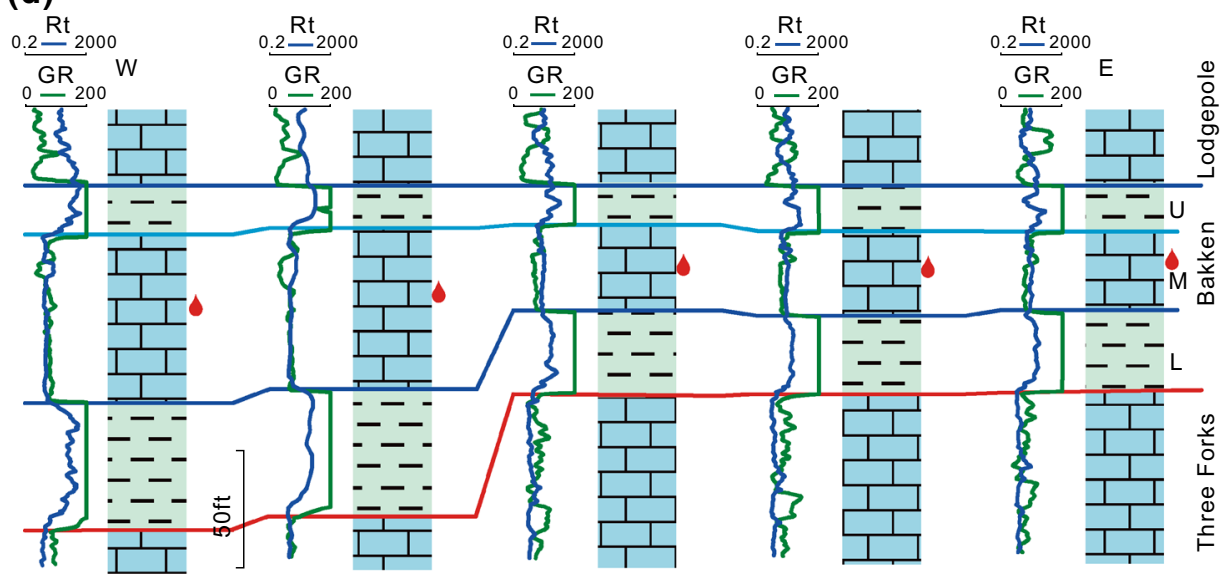

(e)

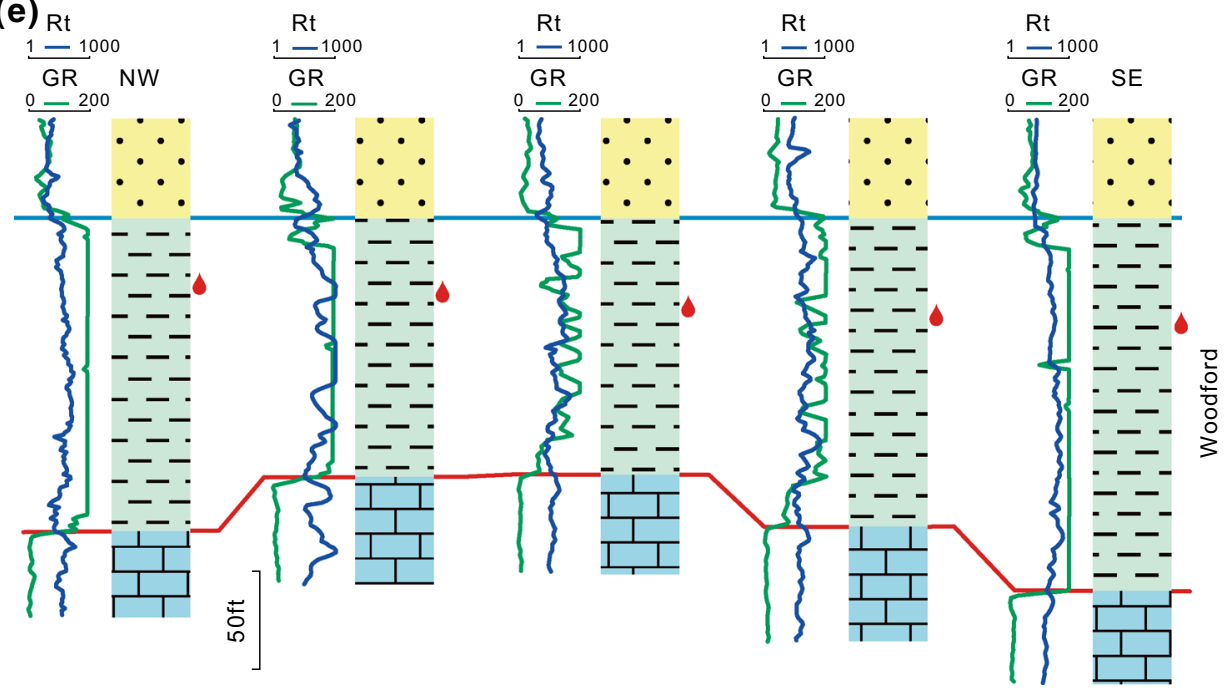

(f)

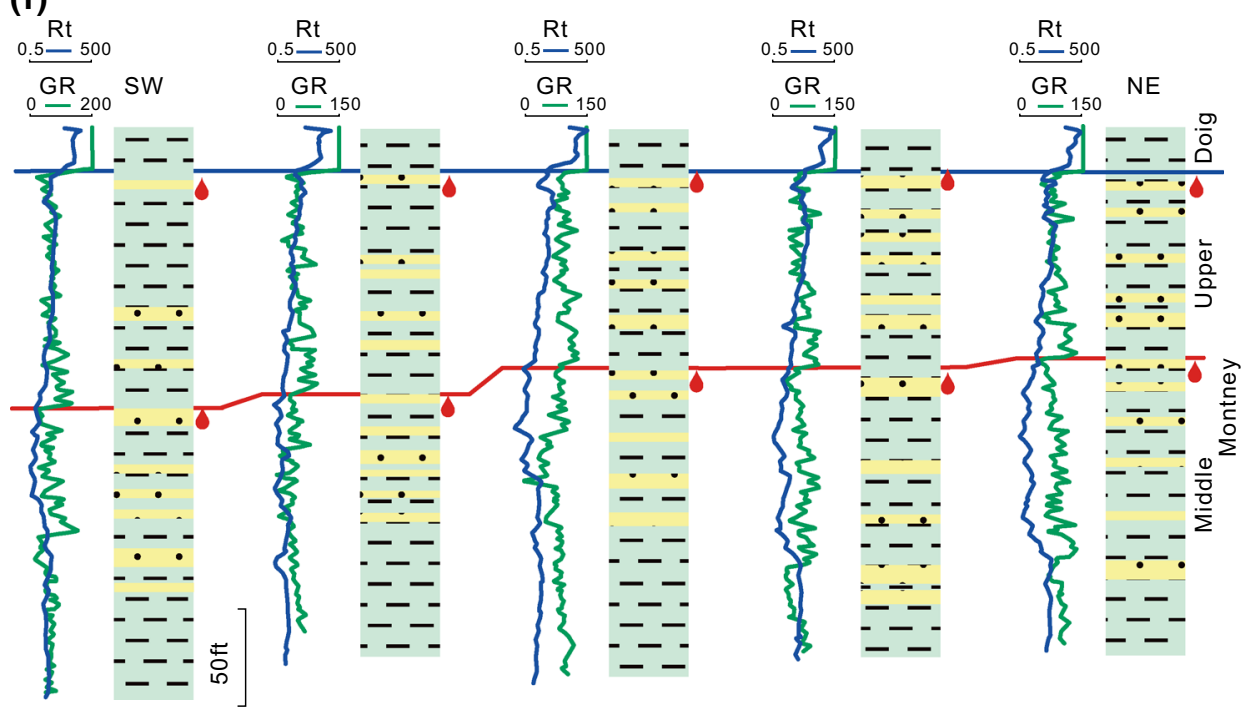

Fig. 6 continued 


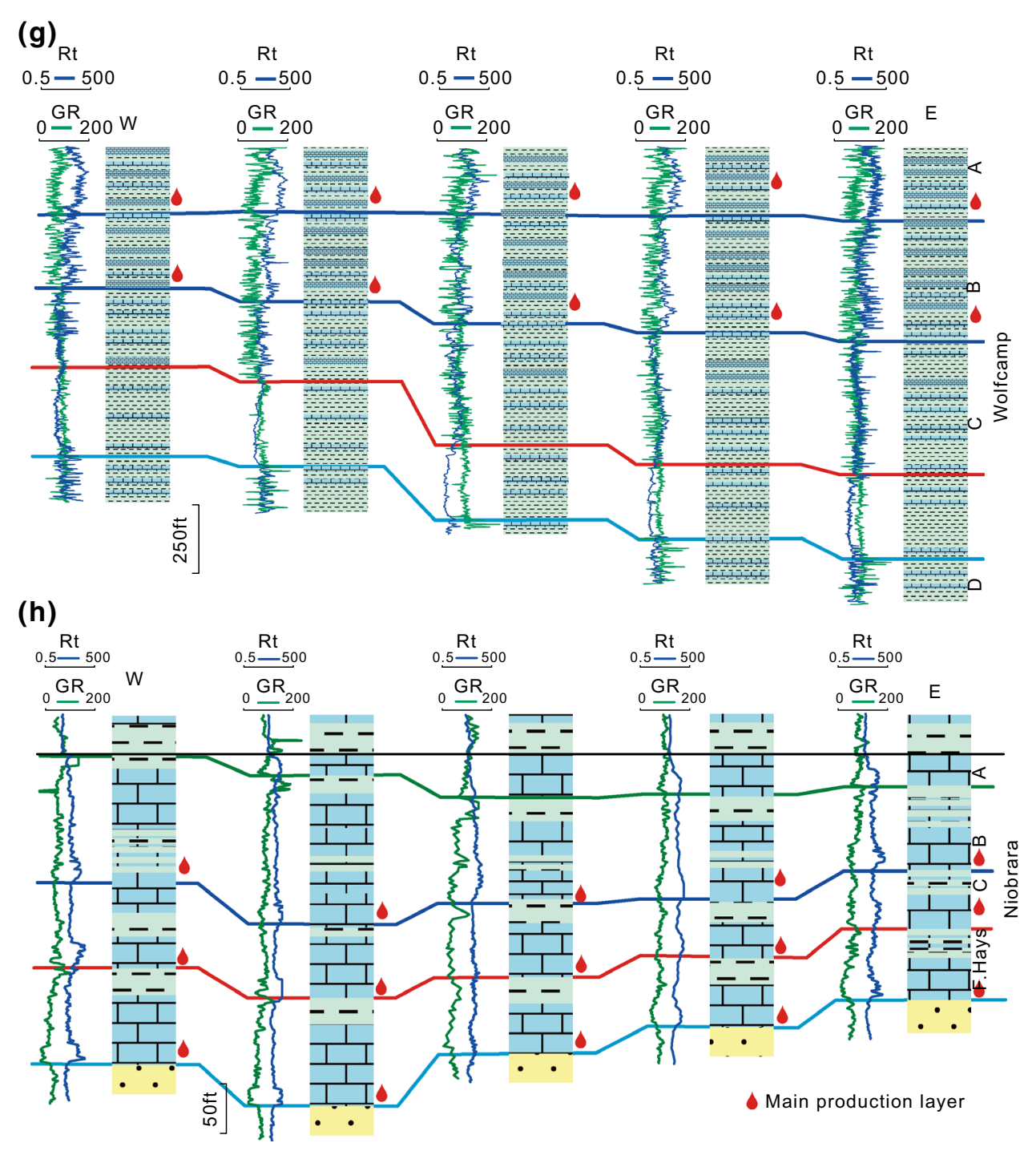

Fig. 6 continued

development target (Andrews 2010; Slatt and O'Brien 2011). In addition, the reservoir rocks in the Duvernay tight oil play in the Alberta Basin, Canada, mainly consist of shale, and the ratio of organic pore porosity to total porosity exceeds $75 \%$ (Chow et al. 1995).

For in-source mud-dominated plays, source rocks and reservoir rocks are interbedded vertically. These mainly consist of source rocks with interbedded thin sandstone or carbonate, and the corresponding shale-formation thickness ratio ranges between 0.6 and 0.9 . In the Montney tight oil play in the Alberta Basin, Canada, thick shale formations are dominant, with a small amount of thin sandstone layers and generally low porosity and permeability (Ghanizadeh et al. 2015), the average TOC is $2.5 \%$, and the reservoirs are featured by small monolayer thickness and relatively low gamma in the whole producing section (Utting et al. 2005). In the Cretaceous Qingshankou Formation in the
Songliao Basin, China, high-quality source rocks with tens of meters thickness are developed and interbedded with a small amount of thin sandstone (Fig. 5f). Similar characteristics are observed in Jurassic Da'anzhai tight oil play in the Sichuan Basin.

For interbedded-source plays, the shale-formation thickness ratio ranges from 0.4 to 0.6 , and source rocks and reservoir rocks are interbedded in roughly equal ratios. In the Wolfcamp tight oil plays in the Permian Basin, US, source rocks and reservoir rocks are difficult to distinguish. However, intensive coring tests and analysis indicate that the whole section consists of centimeter-level dark shale, interbedded with argillaceous dolomite and argillaceous siltstone (Baumgardner et al. 2014). The average TOC of the thin shale is $5.4 \%$, indicating high-quality source rocks. Reservoir rocks and source rocks are difficult to distinguish from core sample photographs due to oil 
Table 2 Basic characteristics of key global basins with tight oil

\begin{tabular}{|c|c|c|c|c|c|c|}
\hline Basin & Formation & Country & Age & Lithology & Type of play & $\begin{array}{l}\text { Sedimentary } \\
\text { environment }\end{array}$ \\
\hline Oman Basin & Athel & Oman & Cambrian & Siliceous shale & Above-source & $\begin{array}{l}\text { Deep-sea anoxic } \\
\text { sediment }\end{array}$ \\
\hline $\begin{array}{l}\text { Anadarko } \\
\text { Basin }\end{array}$ & Cleveland & USA & $\begin{array}{l}\text { Late } \\
\text { Carboniferous }\end{array}$ & Sandstone, shale & Above-source & $\begin{array}{l}\text { Delta-fluvial } \\
\text { sediment }\end{array}$ \\
\hline $\begin{array}{l}\text { Neuquen } \\
\text { Basin }\end{array}$ & Vaca Muerta & Argentina & $\begin{array}{l}\text { Late Jurassic- } \\
\text { Early } \\
\text { Cretaceous }\end{array}$ & Bottom marlstone, top sandy limestone & Above-source & $\begin{array}{l}\text { Lacustrine } \\
\text { sediment }\end{array}$ \\
\hline $\begin{array}{l}\text { Central } \\
\text { Sumatra } \\
\text { Basin }\end{array}$ & Brown & Indonesia & Oligocene & Shale, carbonate & Above-source & $\begin{array}{l}\text { Lacustrine } \\
\text { sediment }\end{array}$ \\
\hline $\begin{array}{r}\text { Thiemann } \\
\text { Pechora }\end{array}$ & $\begin{array}{l}\text { South } \\
\text { Devonian }\end{array}$ & Russia & Devonian & Carbonate, shale & Below-source & $\begin{array}{l}\text { Shallow marine } \\
\text { clastic zone }\end{array}$ \\
\hline $\begin{array}{l}\text { Northwest } \\
\text { Basin }\end{array}$ & Posidonia & $\begin{array}{l}\text { Germany, } \\
\text { Netherlands }\end{array}$ & Jurassic & Thin black shale, marly limestone & Below-source & $\begin{array}{l}\text { Shallow marine } \\
\text { clastic zone }\end{array}$ \\
\hline $\begin{array}{l}\text { Appalachian } \\
\text { Basin }\end{array}$ & $\begin{array}{c}\text { Utica/Point } \\
\text { Pleasant }\end{array}$ & USA & Late Ordovician & $\begin{array}{l}\text { Calcareous shale, carbonaceous shale, } \\
\text { limestone }\end{array}$ & Below-source & $\begin{array}{l}\text { Shallow marine } \\
\text { clastic zone }\end{array}$ \\
\hline $\begin{array}{l}\text { Georgina } \\
\text { Basin }\end{array}$ & $\begin{array}{l}\text { Lower Arthur } \\
\text { Creek }\end{array}$ & Australia & Precambrian & $\begin{array}{l}\text { Thick mudstone with thin interbedded } \\
\text { sandstone }\end{array}$ & Below-source & $\begin{array}{l}\text { Deep-sea anoxic } \\
\text { sediment }\end{array}$ \\
\hline Uinta Basin & $\begin{array}{c}\text { Wasatch/ } \\
\text { Mesa } \\
\text { Verde }\end{array}$ & USA & $\begin{array}{l}\text { Late Paleocene- } \\
\text { Early Eocene }\end{array}$ & $\begin{array}{l}\text { Calcareous mudstone, siltstone, black } \\
\text { shale }\end{array}$ & Beside-source & $\begin{array}{l}\text { Lacustrine } \\
\text { sediment }\end{array}$ \\
\hline $\begin{array}{l}\text { Anadarko } \\
\text { Basin }\end{array}$ & Granite Wash & USA & $\begin{array}{l}\text { Late } \\
\text { Carboniferous- } \\
\text { Permian }\end{array}$ & Conglomerate, shale & Beside-source & $\begin{array}{l}\text { Lacustrine } \\
\text { sediment }\end{array}$ \\
\hline $\begin{array}{l}\text { Anadarko } \\
\text { Basin }\end{array}$ & Woodford & USA & $\begin{array}{l}\text { Devonian-Early } \\
\text { Carboniferous }\end{array}$ & $\begin{array}{l}\text { Siliceous, silty shale, lenticular } \\
\text { limestone }\end{array}$ & In-source & $\begin{array}{l}\text { Shallow marine } \\
\text { clastic zone }\end{array}$ \\
\hline Alberta Basin & Duvernay & Canada & Late Devonian & Interbedded limestone and mudstone & In-source & $\begin{array}{l}\text { Deep-sea anoxic } \\
\text { sediment }\end{array}$ \\
\hline $\begin{array}{l}\text { West } \\
\text { Siberian } \\
\text { Basin }\end{array}$ & Bazhenov & Russia & Late Jurassic & Siliceous, carbonate shale & In-source & $\begin{array}{l}\text { Deep-sea anoxic } \\
\text { sediment }\end{array}$ \\
\hline $\begin{array}{l}\text { Ghadames } \\
\text { Basin }\end{array}$ & Tannezuft & Libya & Early Silurian & Black shale, carbonate & In-source & $\begin{array}{l}\text { Deep-sea anoxic } \\
\text { sediment }\end{array}$ \\
\hline $\begin{array}{l}\text { Anglo-Dutch } \\
\text { Basin }\end{array}$ & $\begin{array}{r}\text { Limburg } \\
\text { Group }\end{array}$ & $\begin{array}{l}\text { Britain, } \\
\text { Netherlands }\end{array}$ & $\begin{array}{l}\text { Late } \\
\text { Carboniferous }\end{array}$ & Interbedded fine sandstone and shale & In-source & $\begin{array}{l}\text { Delta-fluvial } \\
\text { sediment }\end{array}$ \\
\hline $\begin{array}{l}\text { Williston } \\
\text { Basin }\end{array}$ & Bakken & USA & Late Devonian & $\begin{array}{l}\text { Limestone, dolomite, a small amount of } \\
\text { sandstone }\end{array}$ & Between-source & $\begin{array}{l}\text { Shallow marine } \\
\text { clastic zone }\end{array}$ \\
\hline $\begin{array}{r}\text { Cambay } \\
\text { Basin }\end{array}$ & Tharad & India & Eocene & Calcareous shale, siltstone & Between-source & $\begin{array}{l}\text { Shallow marine } \\
\text { clastic zone }\end{array}$ \\
\hline Alberta Basin & Viking & Canada & $\begin{array}{l}\text { Under the } \\
\text { Cretaceous }\end{array}$ & Sandstone, conglomerate, shale & Between-source & $\begin{array}{l}\text { Shallow marine } \\
\text { clastic zone }\end{array}$ \\
\hline $\begin{array}{l}\text { Central Arab } \\
\text { Basin }\end{array}$ & Hanifa & Saudi Arabia & Jurassic & Interbedded marlstone and chalk & Between-source & $\begin{array}{l}\text { Shallow marine } \\
\text { carbonate zone }\end{array}$ \\
\hline Alberta Basin & Cardium & Canada & Late Cretaceous & $\begin{array}{l}\text { Mudstone, sandstone with interbedded } \\
\text { fine-grained conglomerate }\end{array}$ & Between-source & $\begin{array}{l}\text { Delta-fluvial } \\
\text { sediment }\end{array}$ \\
\hline $\begin{array}{l}\text { Eromanga } \\
\text { Basin }\end{array}$ & Merrimelia & Australia & Late Permian & $\begin{array}{l}\text { Interbedded fractured sandstone, } \\
\text { siltstone, and mudstone }\end{array}$ & Between-source & $\begin{array}{l}\text { Delta-fluvial } \\
\text { sediment }\end{array}$ \\
\hline $\begin{array}{l}\text { Qaidam } \\
\text { Basin }\end{array}$ & Dameigou & China & Middle Jurassic & $\begin{array}{l}\text { Black shale, gradually transitioning to } \\
\text { fine sandstone upward }\end{array}$ & Between-source & $\begin{array}{l}\text { Delta-fluvial } \\
\text { sediment }\end{array}$ \\
\hline $\begin{array}{c}\text { Songliao } \\
\text { Basin }\end{array}$ & Qingshankou & China & Late Cretaceous & Thin sandstone with interbedded shale & Between-source & $\begin{array}{l}\text { Lacustrine } \\
\text { sediment }\end{array}$ \\
\hline Ordos Basin & Yanchang & China & Triassic & $\begin{array}{l}\text { Frontal delta lacustrine sediment, delta, } \\
\text { fluvial }\end{array}$ & $\begin{array}{l}\text { Between-source/ } \\
\text { above-source }\end{array}$ & $\begin{array}{l}\text { Lacustrine } \\
\text { sediment }\end{array}$ \\
\hline
\end{tabular}


Table 2 continued

\begin{tabular}{|c|c|c|c|c|c|c|}
\hline Basin & Formation & Country & Age & Lithology & Type of play & $\begin{array}{l}\text { Sedimentary } \\
\text { environment }\end{array}$ \\
\hline $\begin{array}{r}\text { Sichuan } \\
\text { Basin }\end{array}$ & Lianggaoshan & China & Jurassic & Shale, limestone & $\begin{array}{c}\text { Between-source/ } \\
\text { above-source }\end{array}$ & $\begin{array}{l}\text { Lacustrine } \\
\text { sediment }\end{array}$ \\
\hline Illizi Basin & $\begin{array}{l}\text { Aouinet } \\
\text { Ouenine }\end{array}$ & Algeria & Devonian & Shale, thin sandstone & $\begin{array}{l}\text { In-source mud- } \\
\text { dominated }\end{array}$ & $\begin{array}{l}\text { Shallow marine } \\
\text { clastic zone }\end{array}$ \\
\hline $\begin{array}{l}\text { San Joaquin } \\
\text { Basin }\end{array}$ & Monterey & USA & Miocene & Siliceous mudstone, dolomite, chalk & $\begin{array}{l}\text { In-source mud- } \\
\text { dominated }\end{array}$ & $\begin{array}{l}\text { Shallow marine } \\
\text { clastic zone }\end{array}$ \\
\hline Alberta Basin & Montney & Canada & Triassic & Shale, siltstone & $\begin{array}{l}\text { In-source mud- } \\
\text { dominated }\end{array}$ & $\begin{array}{l}\text { Deep-sea anoxic } \\
\text { sediment }\end{array}$ \\
\hline $\begin{array}{l}\text { Messiah } \\
\text { Platform }\end{array}$ & Bals & Romania & Jurassic & Black shale, argillaceous siltstone & $\begin{array}{l}\text { Interbedded- } \\
\text { source }\end{array}$ & $\begin{array}{l}\text { Shallow marine } \\
\text { clastic zone }\end{array}$ \\
\hline Gulf Basin & Eagle Ford & USA & Late Cretaceous & $\begin{array}{l}\text { Shale, carbonate rocks, calcareous } \\
\text { mudstone }\end{array}$ & $\begin{array}{l}\text { Interbedded- } \\
\text { source }\end{array}$ & $\begin{array}{l}\text { Shallow marine } \\
\text { carbonate area }\end{array}$ \\
\hline $\begin{array}{r}\text { Permian } \\
\text { Basin }\end{array}$ & Wolfcamp & USA & Early Permian & Shale, argillaceous limestone, siltstone & $\begin{array}{l}\text { Interbedded- } \\
\text { source }\end{array}$ & $\begin{array}{l}\text { Shallow marine } \\
\text { carbonate zone }\end{array}$ \\
\hline $\begin{array}{l}\text { Reconcavo } \\
\text { Basin }\end{array}$ & Candeias & Brazil & Cretaceous & $\begin{array}{l}\text { Mudstone, sandstone, limestone with } \\
\text { fractures }\end{array}$ & $\begin{array}{l}\text { Interbedded- } \\
\text { source }\end{array}$ & $\begin{array}{l}\text { Lacustrine } \\
\text { sediment }\end{array}$ \\
\hline Denver Basin & Niobrara & USA & Late Cretaceous & $\begin{array}{l}\text { Interbedded chalk and mudstone, } \\
\text { siltstone, sandstone }\end{array}$ & $\begin{array}{l}\text { In-source mud- } \\
\text { subordinated }\end{array}$ & $\begin{array}{l}\text { Shallow marine } \\
\text { carbonate zone }\end{array}$ \\
\hline $\begin{array}{r}\text { Permian } \\
\text { Basin }\end{array}$ & Bone Spring & USA & Early Permian & Siltstone, mudstone, carbonate rocks & $\begin{array}{l}\text { In-source mud- } \\
\text { subordinated }\end{array}$ & $\begin{array}{l}\text { Deep-sea anoxic } \\
\text { sediment }\end{array}$ \\
\hline
\end{tabular}

Sorted as per relevant data of USGS, EIA, and IHS

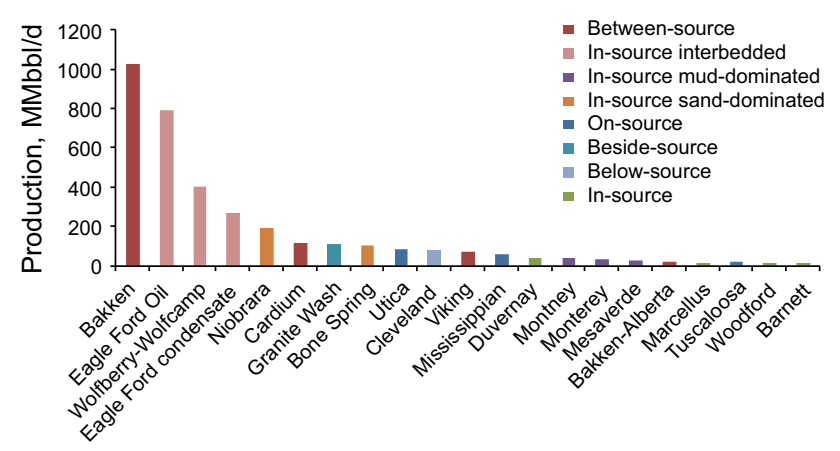

Fig. 7 Production of tight oil plays in North America (Data source Hart Energy 2014)

content and small monolayer thickness, but there is still a low gamma indication in well-logging curves (Figs. $5 \mathrm{~g}$, $6 \mathrm{~g}$ ). The Eagle Ford tight oil play in the Gulf Basin also shares these characteristics, except that the thickness ratios of lower organic-rich shale and upper carbonate are high (Treadgold et al. 2011), which can also be perceived as an on-source play to some extent. The oil content is highest in the middle of the Eagle Ford Formation, and horizontal wells are also mainly drilled along the middle of the formation. A similar case in China is the Jimusar Lucaogou tight oil play in the Junggar Basin, where tuff is interbedded with dolomite vertically.

For in-source mud-subordinated plays, source rocks and reservoir rocks are interbedded vertically, and the shale- formation thickness ratio is below 0.4 with high thickness ratios of sandstone and carbonate. The Niobrara tight oil formation in the Denver Basin is divided into three sections of "A", "B", and "C" (Longman et al. 1998), for each of which the cumulative shale thickness is less than $10 \mathrm{~m}$, while the cumulative chalk thickness is $15-20 \mathrm{~m}$ (Fig. 6h); the average TOC of shale is $3.8 \%$ and the corresponding thickness ratio is less than 0.4. Both the Bone Spring Formation in the Permian Basin and the East Texas Smackover Formation in the Gulf Basin consist of sandstone with multiple interbedded thin organic-rich marine shales (Demis and Milliken 1993; Montgomery 1997).

In some tight oil plays, lithology varies greatly in the vertical direction due to complex geology, and multiple combinations usually coexist, which can be classified by sections. For example, the Eagle Ford shale in the Gulf Basin is an interbedded-source play, but the underlying Buda dolomite tight oil reservoir is a below-source play, and occasionally the overlying Austin chalk reservoir is an above-source play. In Bakken tight carbonate in the Williston Basin, between-source plays are developed, and the Three Forks dolomite below high-quality shale is also a below-source play. In the similar tight oil plays in the Buda Formation (Gulf Basin) and Three Forks Formation (Williston Basin), some companies are recovering tight oil locally. Statistics indicate that tight oil is most abundant in between-source plays (Table 2). 

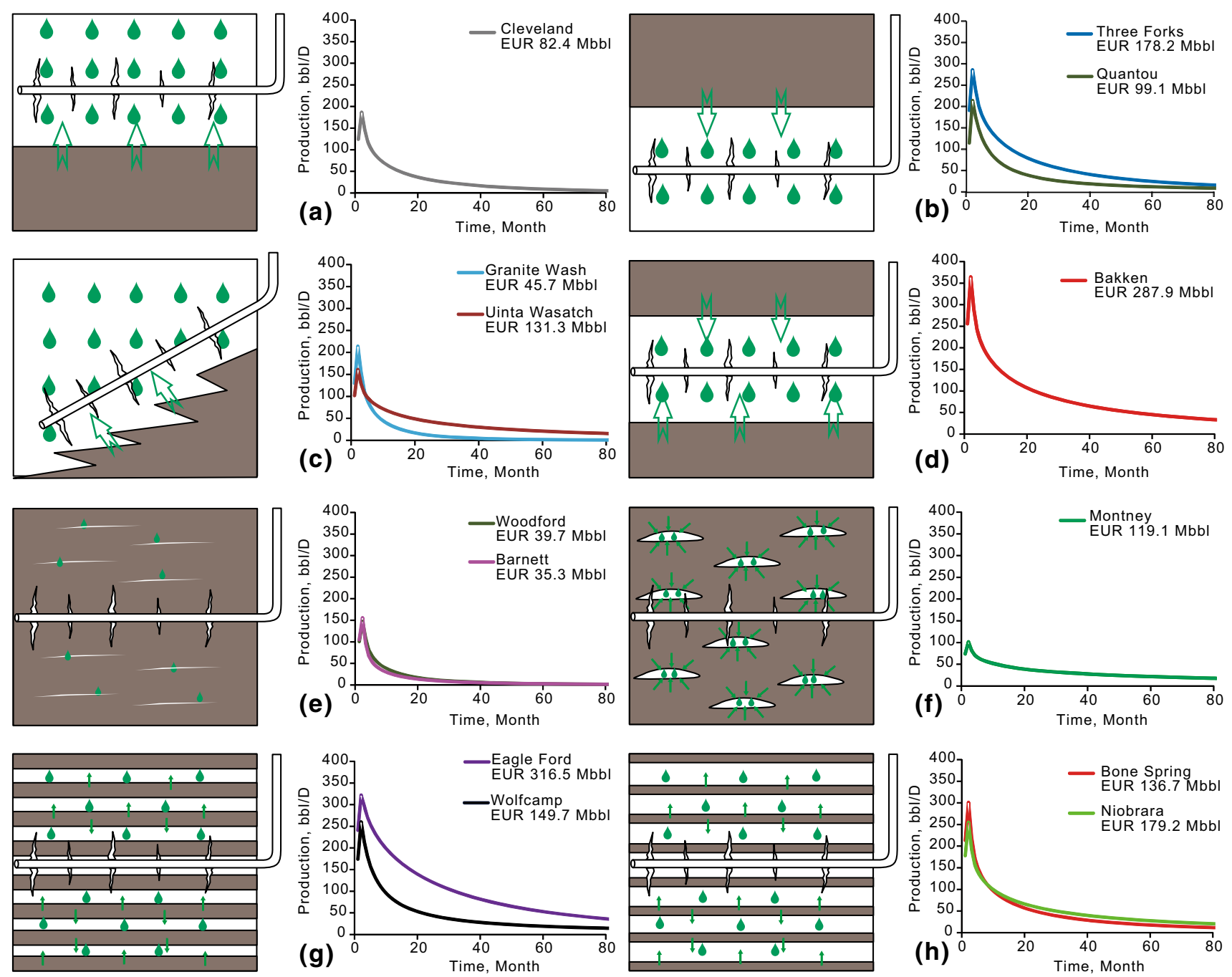

Fig. 8 Hydrocarbon supplying modes and typical production curves of tight oil plays (Data source IHS unconventional database; the production curves represent the average production characteristics of the tight oil plays)

\section{Distribution of favorable tight oil plays}

\subsection{Production performances of different tight oil plays}

Tight oil plays are closely related to the effective development of tight oil. Currently, more than $95 \%$ of the global tight oil is produced in North America, where US tight oil production accounts for more than $90 \%$ (Hart Energy 2014). According to the Hart Energy's (2014) Q3 data, more than 20 tight oil formations had been commercially developed in North America. The top ten tight oil producing formations are Eagle Ford in the Gulf Basin, Bakken in the Williston Basin, WolfberryWolfcamp in the Permian Basin, Niobrara in the Denver Basin, Cardium in the Alberta Basin, Granite Wash in the Anadarko Basin, Bone Spring in the Permian Basin, Utica in the Appalachian Basin, Cleveland in the Anadarko Basin, and Mississippi Lime in the Anadarko Basin. These tight oil plays are mainly between-source, interbedded-source, in-source mud-subordinated, and above-source plays (Fig. 7). Tight oil development in China is still in its preliminary stage. The main producing formation is the Yanchang Formation in the Ordos Basin, which is a between-source play, with annual tight oil production up to 8 million tons. Other tight oil producing formations in China include the Da'anzhai Formation in the Sichuan Basin, Qingshankou Formation in the Songliao Basin, Jimusar Sag Lucaogou Formation in the Junggar Basin, and Shulu Sag Shahejie Formation in the Bohai Bay Basin, but none of them has achieved commercial production. 


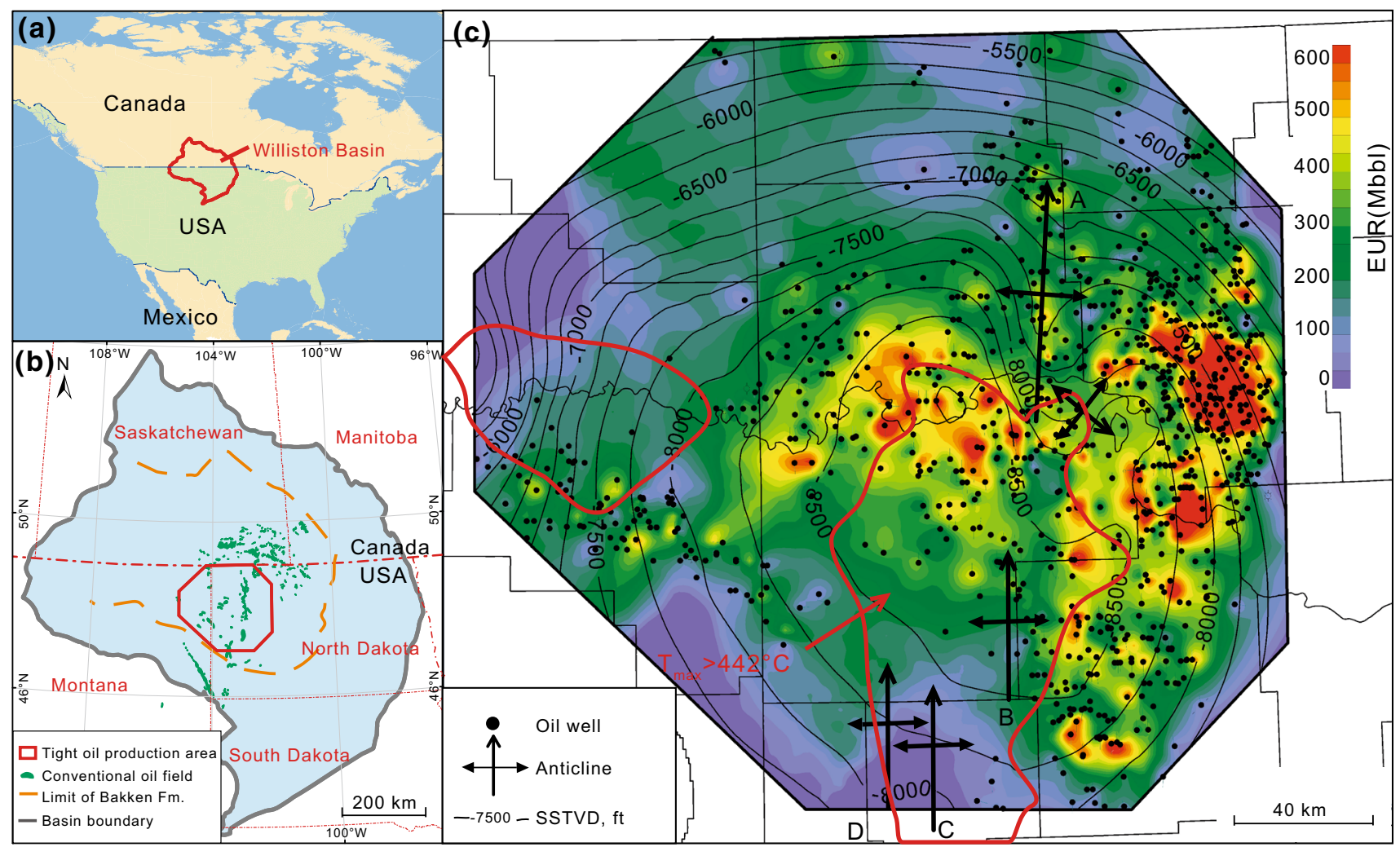

Fig. 9 Tight oil production of Bakken Formation, Williston Basin (Note A represents Nesson Anticline, $B$ represents Little Knife Anticline; $C$ represents TR Anticline; $D$ represents Billings Anticline. Red line represents the $T_{\max }$ of $442{ }^{\circ} \mathrm{C}$. All the wells are horizontal wells with more than 500 days production histories, and the data are from IHS unconventional database, 2014)

\subsection{Analysis of favorable tight oil plays}

According to the hydrocarbon-supply modes, in-source plays, in-source mud-subordinated plays, and in-source interbedded plays are all classified as bidirectional hydrocarbon-supply mode. Source rocks are developed both in the upper part and lower part of reservoir in these plays (Fig. 8) with relatively large contact area between source rocks and reservoirs, which is favorable for hydrocarbon expulsion from source rocks ( $\mathrm{Lu}$ et al. 2012). In-source mud-dominated plays and in-source plays are classified as in-source hydrocarbon-supply mode. They are more favorable than above-source plays with unidirectional hydrocarbon-supply mode. In general, the size of pores and throats in tight oil reservoirs is higher than that in shale, and the hydrocarbon-supply is also partly controlled by fluid buoyancy (Lillis 2013). Therefore, the upward hydrocarbon-supply is more favorable than lateral hydrocarbon-supply, and the worst one is downward hydrocarbon-supply. The resource extent is related to hydrocarbonsupply mode to some extent. At present, high production is achieved in tight oil reservoirs with between-source, insource interbedded, and in-source mud-subordinated plays.
Low clay content and high contents of quartz, feldspar, dolomite, and other brittle minerals are favorable for the implementation of hydraulic fracturing and other reservoir stimulation treatments (Cipolla et al. 2012). In abovesource, below-source, between-source, and beside-source plays, the hydrocarbon mainly accumulates in the tight formations that are adjacent to reservoirs. These tight formations featured a high brittle mineral content and better reservoir quality, which is favorable for development. Insource plays and in-source mud-dominated plays mainly consist of source rock with a relatively high clay content, which is difficult to develop (Miller et al. 2013). Fracture or fracture-pore is the dominant reservoir space with strong heterogeneity in these two plays, and fractures rarely develop on a large scale, which results in difficult reservoir prediction. The in-source mud-subordinated plays and insource interbedded plays fall in between the two abovementioned classifications. However, a tight lithologicstratigraphic reservoir usually develops due to the seal of upper and lower source rocks, which is similar to a conventional reservoir and is easy to develop.

Tight oil reservoirs are adjacent to high-quality source rocks, which leads to relatively little difference in 
hydrocarbon-supply efficiency (Jia et al. 2014). Therefore, comparing with the hydrocarbon-supply mode, reservoir quality is more crucial for the development of tight oil reservoirs. The single-well production performances indicate that the single-well initial production rate (IP) and estimated ultimate recovery (EUR) are significantly higher in the tight oil reservoirs with between-source plays, insource interbedded plays, and in-source mud-subordinated plays, and the corresponding IP and EUR are 200-400 bbl/ $\mathrm{d}$ and 150-300 Mbbl, respectively. The IP and EUR in the tight reservoirs with above-source, below-source, and beside-source plays are 150-250 bbl/d and 50-150 Mbbl, respectively. The IP and EUR in the tight reservoirs with in-source mud-dominated plays and in-source plays are $100-150 \mathrm{bbl} / \mathrm{d}$ and 30-100 Mbbl, respectively.

In addition, the in-source plays of the Anadarko Basin Woodford Shale, Appalachian Basin Marcellus Shale, and Fort Worth Basin Barnett Shale are the major producing areas with huge shale gas production (IHS 2014a, b; Hart Energy 2014). In comparison, there is a great deal of difference in favorable plays between tight oil reservoirs and shale gas reservoirs, which cannot be equally treated. This mainly results from the big difference in physical properties between oil and natural gas. In shale gas reservoirs, the produced gas includes not only the free gas stored in reservoir space but also the adsorbed gas stored in shale. However, the adsorbed oil in shale is mainly heavy oil which is barely produced, with high contents of asphaltene and non-hydrocarbons. In addition, the oil wettability of shale will affect the tight oil recovery factor (Mwangi et al. 2013), and the reservoirs are difficult to fracture due to low brittle mineral content. Therefore, an in-source play cannot be classified as favorable in spite of rich tight oil resources. Similarly, desired development cannot be achieved in insource mud-dominated plays.

In summary, in-source interbedded, in-source mudsubordinated, and between-source plays are the most favorable tight oil plays, followed by above-source, belowsource, and beside-source plays. In-source plays and insource mud-dominated plays are the worst plays.

\subsection{Distribution of favorable zones for development}

Although the type of tight oil play has a significant influence on the production, favorable plays for the development are still controlled by many other factors (Pang et al. 2014). Previous studies believed that tight oil plays are largely free of buoyancy, and structural aspects are neglected in the demonstration of favorable areas (Zou et al. 2012). In fact, statistics show that the present tight oil exploration and development are mainly concentrated in structural slope areas.
The Bakken tight oil play in the Williston Basin is taken as an example, and 884 tight oil production wells are selected for the research in this paper. These wells are completed in 2010-2012, the production times all exceed 500 days and all have entered the stable production stage. All these wells with lateral lengths of more than $3300 \mathrm{ft}$ generally cover the tight oil production areas in the Bakken Basin. The Arps hyperbolic decline model (Robertson 1988) is used to calculate EUR of every well, and a planar EUR distribution (Fig. 9) is established through interpolation. High-production wells are mainly distributed in the basin slope with gentle gradient. There are a few highproduction wells in the basin center and high positions such as anticlines.

The structural slope area adjoins high-quality source rocks. The organic-rich shale in the Upper and Lower Bakken Formation is widely developed (Nordeng and Helms 2010), and maturity is the key factor controlling its hydrocarbon generation capacity. Thus, the high-maturity area in the basin center is considered as hydrocarbon generation center. The highproduction tight oil area of the Bakken Formation is precisely located at the slope which is the edge of the hydrocarbon generation center. Reservoir space is relatively developed in the structural slope area. In general, the slope area is closer to provenience and is featured by higher granularity and better reservoir capacity. The sediment of Bakken Formation mainly comes from the north east. The sedimentary thickness and the siltstone proportion in the middle Bakken Formation increase to the north east. The middle Bakken Formation in the south west mainly consists of dolomite (Sonnenberg and Pramudito 2009). Small-scale "lithologic-stratigraphic traps" often develop in the structural slope area. These "traps" are sweet spots for tight oil development, which can significantly increase tight oil production. In addition, a number of lowamplitude structural traps are developed in the slope area, which is favorable for fracture development (Sonnenberg et al. 2011). Of course, there are also other possible factors that need to be further researched.

In the Gulf Basin Eagle Ford tight oil play, Permian Basin Wolfcamp tight oil play, and some other plays, the drilled wells are all distributed in the basin slope area (Hart Energy 2014).

\section{Conclusions}

(1) Tight oil is most prolific in North America, South America, Africa, and Russia, mainly in foreland basins, craton basins (Paleozoic strata), and continental rift basins (Mesozoic strata). Tight oil resources mainly accumulate in Upper Silurian-Middle Ordovician, Upper Devonian-Lower Carboniferous, Permian, Lower Jurassic, Cretaceous, and Oligocene- 
Miocene, which are well correlated with the six sets of high-quality source rocks globally. Tight reservoirs adjacent to or in the high-quality source rocks are favorable targets for tight oil exploration.

(2) According to the spatial relationships between reservoir rocks and high-quality source rocks, the tight oil plays can be classified into eight types. These are above-source plays, below-source plays, between-source plays, beside-source plays, in-source plays, in-source mud-dominated plays, in-source mud-subordinated plays, and interbedded-source plays. Between-source, above-source, and in-source mud-subordinated plays are the most favorable types, which are the dominant plays in existing major producing areas and the favorable exploration areas. In contrast, in-source mud-dominated, insource, and below-source plays are less prospective for development.

(3) The structural gentle-slope areas with favorable play types are the favorable zones for tight oil development because the structural slope areas are generally characterized by proximity to the mature source rocks, relatively better reservoir space, weak structural activities, and more "sweet spots".

Open Access This article is distributed under the terms of the Creative Commons Attribution 4.0 International License (http://crea tivecommons.org/licenses/by/4.0/), which permits unrestricted use, distribution, and reproduction in any medium, provided you give appropriate credit to the original author(s) and the source, provide a link to the Creative Commons license, and indicate if changes were made.

\section{References}

Ambrose WA, Hentz TF, Carr DL, et al. Oil- and gas-production plays and trends in the Pennsylvanian Marmaton Group and Cleveland Formation, Anadarko Basin, north Texas and western Oklahoma. Report of Investigations-University of Texas at Austin. Bureau of Economic Geology. 2011, p. 67-98.

Andrews RD. Production decline curves and payout thresholds of horizontal Woodford wells in the Arkoma Basin, Oklahoma (Part 2). Shale Shak. 2010;60(4):147-56.

Angulo S, Buatois LA. Integrating depositional models, ichnology, and sequence stratigraphy in reservoir characterization: The middle member of the Devonian-Carboniferous Bakken Formation of subsurface southeastern Saskatchewan revisited. AAPG Bull. 2012;96(6):1017-43.

Baumgardner RW, Hamlin HS, Rowel HD. High-resolution core studies of Wolfcamp/Leonard basinal facies, southern Midland Basin, Texas. AAPG Southwest Section Annual Convention, Midland. 2014;5:11-4. http://www.searchanddiscovery.com/pdfz/documents/ 2014/10607baumgardner/ndx_baumgardner.pdf.html.
Bebout DG, White WA, Garrett CM, et al. Atlas of major central and eastern Gulf Coast gas reservoirs. Austin: Bureau of Economic Geology, University of Texas at Austin; 1992. p. 88.

BP. Statistical review of world energy. 2015. http://www.bp.com/ statistics.

C \& C Reservoirs. Field analogs, North America. Houston, 2014.

Chow N, Wendte J, Stasiuk LD. Productivity versus preservation controls on two organic-rich carbonate facies in the Devonian of Alberta: sedimentological and organic petrological evidence. Bull Can Pet Geol. 1995;43(4):433-60.

Cipolla C, Lewis R, Maxwell S, et al. Appraising unconventional resource plays: separating reservoir quality from completion effectiveness. International Petroleum Technology Conference 2012, IPTC. 2012;2:1524-50.

CNPC. Unconventional hydrocarbon potential analysis and future strategic zone selection in global main areas. Beijing, 2014. (unpublished).

Demis WD, Milliken JV. Shongaloo field: a recent Smackover (Jurassic) discovery in the Arkansas-Louisiana State Line Graben. Gulf Coast Assoc Geol Soc Trans. 1993;43:109-19.

EIA. Review of emerging resources: US shale gas and shale oil plays. 2011. http://www.eia.gov/analysis/studies/usshalegas/.

EIA. Technically recoverable shale oil and shale gas resources: an assessment of 137 Shale Formations in 41 Countries Outside the United States. 2013. http://www.eia.gov/analysis/studies/world shalegas/.

Ghanizadeh A, Clarkson CR, Aquino S, et al. Petrophysical and geomechanical characteristics of Canadian tight oil and liquidrich gas reservoirs: I. Pore network and permeability characterization. Fuel. 2015;153:664-81.

Hart Energy. North American Shale Quarterly. 2014. http://nasq. hartenergy.com/.

Hentz TF, Ruppel SC. Regional lithostratigraphy of the Eagle Ford Shale: Maverick Basin to East Texas Basin. Gulf Coast Assoc Geol Soc Trans. 2010;60:325-38.

IHS. Going global: predicting the next tight oil revolution. 2014. http://www.ihs.com/products/cera/.

IHS. Unconventional Frontier: prospects for tight oil in North America. 2014. http://www.ihs.com/products/cera/.

Jarvie DM. Shale resource systems for oil and gas: part 2. Shale-oil resource systems. AAPG Mem. 2012;97:89-119.

Jia CZ, Zheng M, Zhang YF. Four important theoretical issues of unconventional petroleum geology. Acta Pet Sin. 2014;35(1):1-10 (in Chinese).

Jia CZ, Zou CN, Li JZ, et al. Assessment criteria, main types, basic features and resource prospects of the tight oil in China. Acta Pet Sin. 2012;33(3):343-9 (in Chinese).

Klemme HD, Ulmishek GF. Effective petroleum source rocks of the world: stratigraphic distribution and controlling depositional factors. AAPG Bull. 1991;75(12):1809-51.

Kuang LC, Tang Y, Lei DW, et al. Formation conditions and exploration potential of tight oil in the Permian saline lacustrine dolomitic rock, Junggar Basin, NW China. Pet Explor Dev. 2012;39(6):657-67 (in Chinese).

Liang DG, Ran LH, Dai DS, et al. A re-recognition of the prospecting potential of Jurassic large-area and non-conventional oils in the central-northern Sichuan Basin. Acta Pet Sin. 2011;32(1):8-17 (in Chinese).

Lillis PG. Review of oil families and their petroleum systems of the Williston Basin. Mt Geol. 2013;50(1):5-31.

Longman MW, Luneau BA, Landon SM. Nature and distribution of Niobrara lithologies in the Cretaceous Western Interior Seaway of the Rocky Mountain Region. Mt Geol Rocky Mt Assoc Geol. 1998;35(4):137-70. 
Lu SF, Huang WB, Chen FW, et al. Classification and evaluation criteria of shale oil and gas resources: discussion and application. Pet Explor Dev. 2012;39(2):249-56 (in Chinese).

Ma F, Wang HJ, Zhang GY, et al. Tight oil accumulation characteristics and selection criteria for potential basins. Xinjiang Pet Geo. 2014;35(2):243-7 (in Chinese).

Miller C, Hamilton D, Sturm S, et al. Evaluating the impact of mineralogy, natural fractures and in situ stresses on hydraulically induced fracture system geometry in horizontal shale wells. Society of Petroleum Engineers-SPE Hydraulic Fracturing Technology Conference. 2013, p. 695-710.

Mitchell J. Horizontal drilling of deep granite wash reservoirs, Anadarko Basin, Oklahoma and Texas. Shale Shak. 2011;62(2):118-67.

Montgomery SL. Permian Bone Spring Formation: sandstone play in the Delaware Basin, Part I—slope. AAPG Bull. 1997;81(8):1239-58.

Mwangi P, Thyne G, Rao D. Extensive experimental wettability study in sandstone and carbonate-oil-brine systems: part 1-screening tool development. International Symposium of the Society of Core Analysts held in Napa Valley, California, USA. 2013. http://www. scaweb.org/assets/papers/2013_papers/SCA2013-084.pdf.

National Resources Canada. North American tight oil. 2012. http:// www.nrcan.gc.ca/energy/sources/crude/2114\#oil1.

Nordeng SH, Helms LD. Bakken source system-Three Forks Formation assessment. North Dakota Department of Mineral Resources. 2010. p. 22.

Pang XQ, Jia CZ, Wang WY. Petroleum geology features and research developments of hydrocarbon accumulation in deep petroliferous basins. Pet Sci. 2015;1:1-53.

Pang XQ, Jiang ZX, Huang HD, et al. Formation mechanisms, distribution models, and prediction of superimposed, continuous hydrocarbon reservoirs. Acta Pet Sin. 2014;35(5):795-828 (in Chinese).

Robertson S. Generalized hyperbolic equation. 1988, SPE-18731-MS.

Slatt RM, O'Brien NR. Pore types in the Barnett and Woodford gas shales: contribution to understanding gas storage and migration pathways in fine-grained rocks. AAPG Bull. 2011;95(12): 2017-30.

Sonnenberg SA, Pramudito A. Petroleum geology of the giant Elm Coulee field, Williston Basin. AAPG Bull. 2009;93:1127-53.
Sonnenberg SA, LeFever JA, Hill R. Fracturing in the Bakken Petroleum System, Williston Basin. In: Robinson JW, LeFever JA, Gaswirth SB, editors. The Bakken-Three Forks Petroleum System in the Williston Basin. Denver: Rocky Mountain Association of Geologists; 2011. p. 393-417.

The unconventional oil subgroup of the resources \& supply task group. Potential of North American unconventional oil resource. Working Document of the NPC North American Resource Development Study. 2011. p. 8-11.

Treadgold G, Campbell B, McLain W, et al. Eagle Ford prospecting with 3-D seismic data within a tectonic and depositional system framework. Lead Edge. 2011;30(1):48-53.

Utting J, Zonneveld JP, MacNaughton RB, et al. Palynostratigraphy, lithostratigraphy and thermal maturity of the Lower Triassic Toad and Grayling, and Montney Formations of western Canada, and comparisons with coeval rocks of the Sverdrup Basin, Nunavut. Bull Can Pet Geol. 2005;53(1):5-24.

Wang JL, Feng LY, Mohr S, et al. China's unconventional oil: a review of its resources and outlook for long-term production. Energy. 2015;82:31-42.

Yang H, Li SX, Liu XY. Characteristics and resource prospects of tight oil and shale oil in Ordos Basin. Acta Pet Sin. 2013;34(1):1-11 (in Chinese).

Zhang K, Zhang KY, Zhang LL. On tight and shale oil and gas. Nat Gas Ind. 2013;33(9):17-22 (in Chinese).

Zhao JZ, Li J, Cao Q, et al. Hydrocarbon accumulation patterns of large tight oil and gas fields. Oil Gas Geol. 2013;34(5):573-83 (in Chinese).

Zhou QF, Yang GF. Definition and application of tight oil and shale oil terms. Oil Gas Geol. 2012;33(4):541-4 (in Chinese).

Zou CN, Yang Z, Zhang GS, et al. Conventional and unconventional petroleum "orderly accumulation" theoretical recognition and practical significance. Pet Explor Dev. 2014;41(1):14-27 (in Chinese).

Zou CN, Zhu RK, Wu ST, et al. Types, characteristics, genesis and prospects of conventional and unconventional hydrocarbon accumulations: taking tight oil and tight gas in China as an instance. Acta Pet Sin. 2012;33(2):173-87 (in Chinese). 